\title{
SUMBERDAYA GENETIK IKAN, ASET YANG MASIH TIDUR
}

\author{
Muhammad Hunaina Fariduddin Ath-thar') dan Rudhy Gustiano**) \\ *Balai Riset Perikanan Budidaya Air Tawar \\ Jl. Sempur No. 1, Bogor 16154 \\ E-mail: mhfariduddinaththar@ yahoo.co.id \\ ${ }^{*}$ Balai Riset Budidaya Ikan Hias \\ Jl. Perikanan No. 13, Pancoran Mas, Depok
}

\begin{abstract}
ABSTRAK
Berkaitan dengan sumberdaya alam kekayaan sumberdaya genetik ikan, Indonesia merupakan negara terkaya di dunia. Kajian mengenai sumberdaya genetik atau keanekaragaman hayati memerlukan suatu pendekatan genetika evolusi. Seiring perkembangan zaman, keanekaragaman hayati yang kita miliki harus diarahkan untuk memperkuat ketahanan pangan dalam negeri. Untuk itu, dibutuhkan spesies ikan yang mudah dibudidayakan, harganya relatif terjangkau oleh masyarakat dan produktivitasnya tinggi. Jenis nila, patin, dan lele diharapkan dapat mengawal ketahanan pangan nasional yang dapat dipersiapkan untuk membantu ketergantungan masyarakat terhadap unggas. Dari segi pengelolaan dan pelestarian, spesies-spesies yang memainkan peranan penting dalam proses ekologi akan mendapatkan prioritas yang lebih tinggi untuk dikonservasi. Pendekatan ekologi dengan sistematik dapat dijadikan acuan ke mana program konservasi yang akan kita jalankan untuk melindungi kekayaan hayati yang kita miliki.
\end{abstract}

\section{KATAKUNC: keanekaragaman hayati, ketaha- nan pangan, dan konservasi}

\section{PENDAHULUAN}

Sudah bukan rahasia umum Indonesia merupakan salah satu negara yang dikaruniai kekayaan alam berlimpah. Namun satu hal yang patut dipikirkan adalah, sudahkah bangsa dan rakyat Indonesia menikmati kekayaan tersebut. Nampaknya, sebagaimana banyak negara yang memiliki kekayaan alam berlimpah di dunia belum dapat memanfaatkan kekayaan tersebut secara optimal dan lestari untuk pembangunan jangka panjang. Eksploitasi besar-besaran tanpa mempertimbangkan keberlanjutan sumberdaya yang diambil merupakan suatu gambaran yang sudah umum. Kegiatan-kegiatan eksplorasi yang telah banyak dilakukan juga tidak banyak berdampak kepada peningkatan kesejahteraan masyarakat luas dan ironis pada masyarakat di mana sumberdaya tersebut diperoleh.

Berkaitan dengan sumberdaya alam kekayaan sumberdaya genetik ikan, Indonesia merupakan negara terkaya di dunia. Menurut FAO (2002), kekayaan jenis yang ada di Indonesia lebih dari 4.644 jumlahnya. Merupakan pekerjaan rumah yang harus segera dibereskan berapa sebenamya jumlah jenis yang ada, termasuk yang belum didokumentasikan dan jumlah yang hilang setiap tahun. Jangan sampai terjadi jumlah yang besar hanya tinggal menjadi catatan dan koleksi mati di museum sebelum dapat dimanfaatkan secara optimal. Sampai saat ini, kurang dari 50 spesies yang sudah dapat dibudidayakan (Gustiano, 2006).

Ilustrasi di atas memberikan gambaran bahwa betapa kayanya Indonesia akan keragaman sumberdaya genetik ikan yang dapat digunakan menjadi aset pembangunan apabila dapat dikelola dengan baik secara cerdas untuk menghasilkan sesuatu yang bermanfaat. Patut dicatat, sumberdaya genetik ikan belum termasuk akan jenis-jenis biota lainnya yang ada di perairan seperti udang, moluska (kerang, cumi, teripang dan lain-lain), rumput laut, dan karang di mana Indonesia menjadi pusat keanekaragaman dunia. Pada tulisan ini akan diulas bahasan tentang sumberdaya genetik, pemanfaatan untuk pangan dan pengelolaannya.

\section{SUMBERDAYA GENETIK}

Kajian mengenai sumberdaya genetik atau keanekaragaman hayati telah sering kita dengar dan dibahas di berbagai media dan forum. Namun demikian teknik penentuan keanekaragaman hayati itu sendiri belum dipahami orang banyak. Penentuan jenis pada zaman dahulu lebih banyak ditetapkan oleh para taksonomis berdasarkan identifikasi karakter untuk membedakan satu spesies dengan lainnya. Sejalan dengan perkembangan pengetahuan, biologi konsep dikembangkan berdasarkan kemampuan suatu jenis melakukan melakukan reproduksi dengan jenis lainnya. Perkembangan pengetahuan terkini 
adalah dengan melakukan pendekatan evolusi secara genetik menggunakan karakter primitif dan modem. Pendekatan evolusi di atas bersama-sama dengan taksonomi merupakan ilmu sistematika modem. Secara khusus, bidang yang menangani evolusi secara genetik dikenal sebagai pohon keturunan (phylogeny). Untuk orang awam seringkali keliru menafsirkan pohon keturunan dengan kemiripan (phenotypic similarity) atau kekerabatan (genetic relationship). Ketiganya nampak serupa tapi tidak sama dalam analisis dan filosofinya. Untuk memahami ini dibutuhkan suatu keahlian khusus. Berdasarkan pendekatan keanekaragaman di atas, dengan tidak mengecilkan arti dan peran para taksonomis terdahulu, sangat diperlukan untuk inventarisasi, identifikasi, dan karakterisasi sumberdaya genetik yang dimiliki menggunakan pendekatan modem. Sebagai contoh pada studi ikan patin di Asia yang dilakukan oleh penulis, sebelumnya diketahui ada 48 nominal spesies yang ada di dunia. Setelah studi phylogeny dan taksonomi dilakukan, jumlah spesies yang valid hanya ada 28 spesies dengan 6
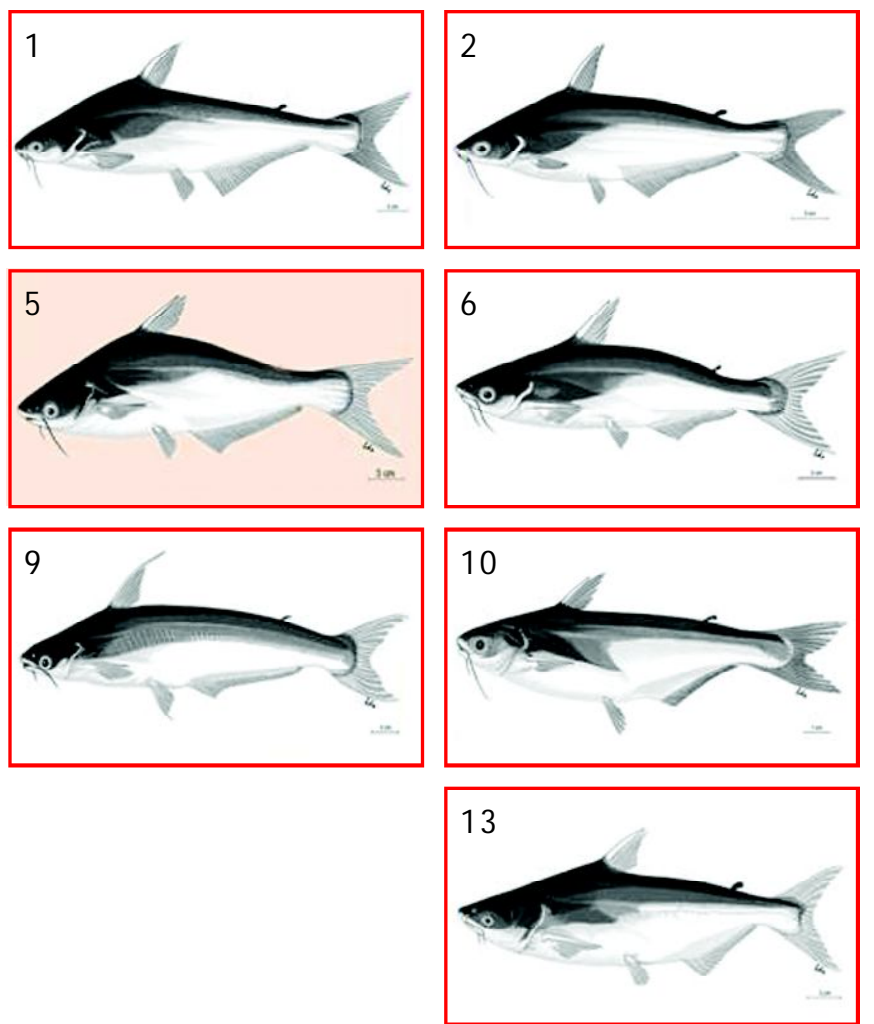

di antaranya dideskripsi sebagai spesies baru dan $14 \mathrm{di}$ antaranya asli Indonesia (Gambar 1).

Dengan demikian sebanyak 26 spesies yang dikemukakan oleh para taksonomis dahulu banyak yang merupakan sinonini. Hal tersebut terjadi karena pada zaman dahulu para taksonomis bekerja sendiri-sendiri pada wilayah yang berbeda dan belum ada jejaring yang memungkinkan mereka saling tukar-menukar informasi untuk melakukan konfirmasi. Adanya konsep ilmu pengetahuan yang baru perlu disimak lagi untuk mendapatkan kepastian akan sumberdaya genetik yang ada berdasarkan ilmu pengetahuan terkini. Pemahaman akan sumberdaya genetik di masa mendatang akan sangat membantu dan mempercepat proses optimalisasinya untuk kebutuhan pangan dan pembangunan.

\section{KETAHANAN PANGAN}

Ketahanan pangan atau Food security berarti ketersediaan pangan harus terjamin dan daya beli
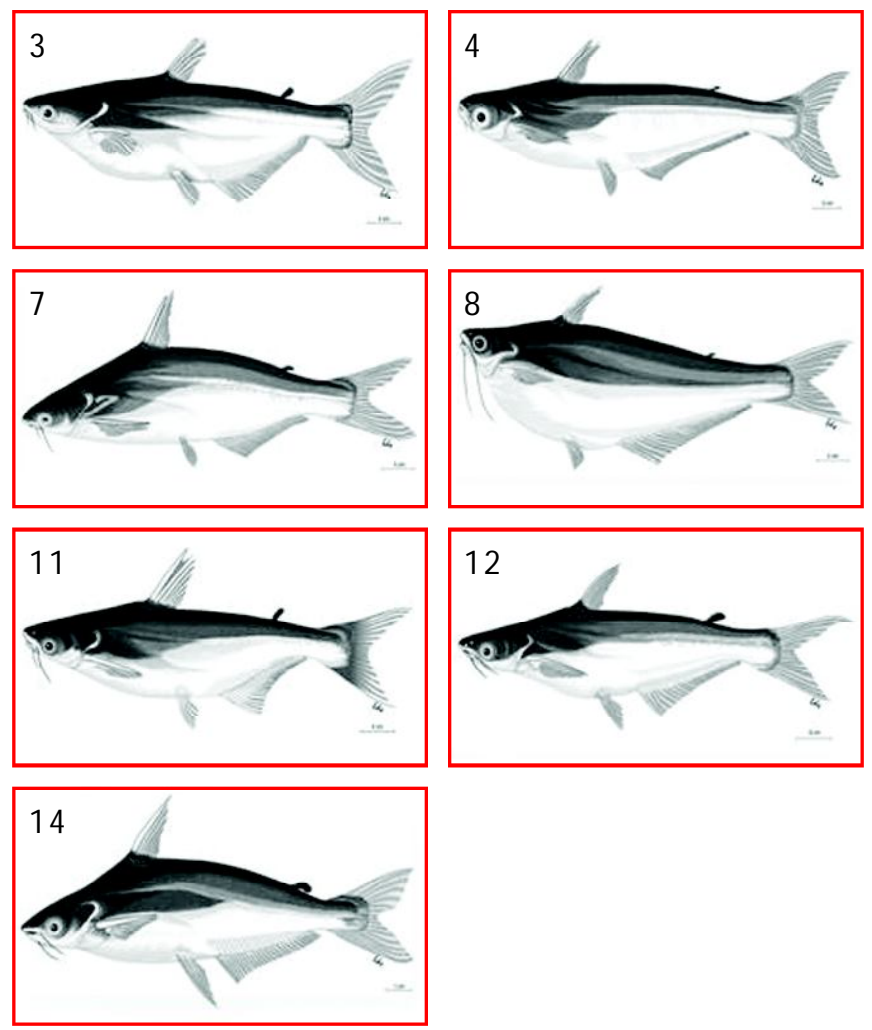

Gambar 1. Beberapa contoh spesies patin di Indonesia (1. Helicophagus typus (Bleeker, 1858); 2. Helicophagus waandersii (Bleeker, 1858); 3. Pangasianodon hypophthalmus (Sauvage, 1878); 4. Pteropangasius micronemus (Bleeker, 1847); 5. Pangasius lithostoma (Roberts, 1989); 6. Pangasius humeralis (Roberts, 1989); 7. Pangasius nieuwenhuisii (Popta, 1904); 8. Pangasius macronema (Bleeker, 1851); 9. Pangasius polyuranodon (Bleeker, 1852); 10. Pangasius mahakamensis (Pouyaud, Gustiano, \& Teugels, 2002); 11. Pangasius djambal (Bleeker, 1846); 12. Pangasius rheophilus (Pouyaud \& Teugels, 2000); 13. Pangasius nasutus, 14. Pangasius kunyit (Pouyaud, Teugels, \& Legendre, 1999)) 
masyarakat untuk membeli kebutuhan pangan harus tercipta. Namun kini, kenyataan yang dihadapi adalah kerapuhan pangan atau food fragility. Banyak kecemasan di negara berkembang akan kelangkaan pangan, baik yang reatif ataupun absolut, secara kuantitatif mau kualitatif.

Kini saatnya harus mulai dipikirkan cara menanggulangi kerapuhan pangan kualitatif, yakni kondisi masyarakat yang hanya memilih makanan asal cukup mengenyangkan, tanpa pertimbangan kehendak untuk menyehatkan dan mencerdaskan. Padahal, akibat yang ditimbulkan adalah terciptanya generasi yang kurang produktif, serta berkualitas lemah untuk bersaing antar bangsa. Indikator kurangnya asupan protein yang sangat penting dalam menyehatkan dan mencerdaskan adalah masih relatif rendahnya asupan protein di Indonesia jika dibandingkan dengan negara-negara tetangga. Bagi kita yang memiliki lahan perikanan membentang luas, kiranya memiliki peluang untuk memaksa masyarakat mengkonsumsi ikan yang berprotein tinggi dan mengandung omega tiga.

Fakta di lapangan memang menunjukkan permintaan terhadap ikan dari hari ke hari meningkat. Kenaikan permintaan itu tidak hanya di dalam negeri tapi juga di luar negeri. Menurut Nurdjana (2008), ada empat hal yang menyebabkan permintaan ikan tinggi. Pertama manusia ingin umurnya panjang, sehingga orang-orang memilih makanan sehat, yang tak mengandung kolesterol dan tekanan darah. Kedua, di negara maju manusia sangat sibuk. Untuk menjadi profesional mereka menghindari boros waktu termasuk dalam pola makan. Sehingga salah satu yang diperlukan adalah makanan siap saji dari ikan. Ketiga, ke depan bisnis makanan yang banyak diterima orang adalah ikan karena tidak ada satupun agama yang melarangnya. Keempat, fakta menunjukkan hewan darat bias menjadi inang penyakit yang menular ke manusia, seperti med cow, antrax, dan flu burung. Sehingga orang mencari makanan yang aman dan ikan menjadi pilihannya. Kini permintaan untuk ikan ke luar negeri cukup besar dan hanya ikan yang ekspornya tidak dibatas kuota. Karena permintaan besar, kita harus pintar membagi untuk ketahanan pangan dalam negeri.

Untuk memperkuat ketahanan pangan dalam negeri dibutuhkan, spesies ikan yang mudah dibudidayakan, harganya relatif terjangkau masyarakat, dan produktivitasnya tinggi. Jenis nila, patin, dan lele diharapkan dapat mengawal ketahanan pangan nasional yang dapat dipersiapkan untuk membantu ketergantungan masyarakat terhadap unggas. Untuk mewujudkan ketahanan pangan nasional tinggal kemauan saja. Dukungan pengembangan bibit unggul ketiga jenis ikan di atas telah dilakukan agar aktivitas budidaya lebih efisien.
Diharapkan, dalam proses ketahanan pangan yang bersumber dari jenis ikan ini, memasang target sebesar $15 \%$ saja bisa menggantikan ketergantungan masyarakat Indonesia terhadap ayam dan telurnya secara bertahap. Dengan adanya flu burung beban untuk mengembangkan ketahanan pangan dari unggas cukup berat. Karena itu, dapat digantikan dengan ikan nila, lele, dan patin.

\section{PENGELOLAAN DAN PELESTARIAN}

Banyak negara di kawasan Asia yang perekonomiannya sebagian besar masih tergantung pada sumberdaya biologi. Telah muncul kesadaran dari banyak lembaga konservasi terhadap kegiatan yang sedang berlangsung seperti penggundulan hutan, pembendungan waduk, ekplorasi laut sebagai kegiatan yang tidak berkelanjutan. Namun demikian sering dihadapi bahwa ekploitasi sumberdaya alam dan konservasi sering berbenturan kepentingan. Meskipun telah tersedia hukum untuk mengefektifkan konservasi keanekaragaman hayati namun pelaksanaan dan pengawasannya menunjukkan banyak masalah. Tentu saja hal ini akan sangat mempengaruhi keberadaan spesies-spesies ikan yang kita miliki. Mengingat betapa pentingnya peranan sumberdaya genetik, sudah seharusnya dilakukan penegakan hukum secara menyeluruh dan keterpaduan dalam pengelolaan aset yang kita miliki.

Dewasa ini berkembang suatu pandangan bahwa kriteria utama untuk melakukan konservasi (pelestarian) adalah perbedaan phylogenetic (Stiassny, 1994; Vrijenhoek, 1998). Dari sisi taksonomi, perbedaan yang jauh dari suatu biota memberikan kontribusi yang besar terhadap keseluruhan keanekaragaman hayati. Oleh karena itu, perbedaan phylogenetic sudah sepatutnya memperoleh prioritas yang lebih tinggi untuk keperluan konservasi (Bowen, 1999). Usulan pendekatan konservasi ini memiliki banyak kemiripan dengan pendekatan yang memberikan prioritas lebih tinggi kepada area yang memiliki banyak endemik spesies.

Perbedaan antara pendekatan ekologi dengan sistematik adalah bahwa pada konservasi dari suatu ekosistem tidak tergantung pada keberadaan spesies yang terancam punah atau jenis endemik, melainkan untuk mencegah hilangnya keanekaragaman hayati dari pengrusakan habitat. Oleh karena itu, spesies-spesies yang memainkan peranan penting dalam proses ekologi akan mendapatkan prioritas yang lebih tinggi untuk dikonservasi. Dua pendekatan di atas dapat dijadikan acuan ke mana program konservasi yang akan kita jalankan untuk melindungi kekayaan hayati yang kita miliki. 
Upaya-upaya pelestarian plasma nutfah dapat dilakukan dengan: 1) penetapan dan pembiakan ikan yang populasinya terbatas, 2) penetapan wilayah konservasi, 3) pengaturan lalu lintas plasma nutfah, 4) restocking berbasis masyarakat, 5) pembentukan wadah koleksi, 6) pengembangan jaringan pemanfaatan dan pelestarian sumberdaya plasma nutfah (Nugroho, 2001). Namun demikian, nampaknya perlu diwujudkan suatu institusi yang langsung bertanggung jawab terhadap kekayaan sumberdaya genetik ikan. Tidak sebagaimana yang ada saat ini, penanganan sumberdaya genetik ikan masih lebih banyak dalam bentuk wacana, bukan prioritas dan berada di bawah koordinasi institusi terkait.

\section{DAFTAR ACUAN}

Bowen, B.W. 1999. Preserving genes, species, or ecosystems? Healing the fractured foundations of conservation policy. Molecular Ecology, 8: S5-S10

FAO. 2002. The State of World Fisheries and Aquaculture. FAO, Rome, p. 21-25
Gustiano, R. 2007. Perbaikan mutu genetik ikan nila. Kumpulan Makalah Bidang Riset Perikanan Budidaya, Simposium Kelautan dan Perikanan. Jakarta, $6 \mathrm{hlm}$.

Nugroho, E., Amarulloh, H., \& Sukadi, F. 2001. Pemuliaan dan Prospek Perbenihan. Warta Pen. Perik. Indonesia, 7 (4): 18-23

Nurdjana, M.L. 2008. Indonesian Aquaculture Development. RCA International Workshop on Innovative Technologies for Eco-Friendly Fish Farm M anagement and Production of Safe Aquaculture Foods, p. 13-17

Stiassny, M.L.J. \& DePinna, M.C.C. 1994. Basal taxa and the role of cladistic patterns in the evaluation of conservation priorities: a view from freshwater. In: Systematics and Conservation Evaluation, Systematics Association Special Volume, Oxford University Press. (Eds). Forey, P., Humphreys, C.J., \& Vane-Wright, R.I., p. 235-249

Vrijenhoek, R.C. 1998. Conservation genetics of freshwater fish. J. of Fish Biology, (Supplement A): 53 : 394-412. 